\title{
Pengaruh Perbedaan Metode Ekstraksi Rimpang Kunyit (Curcuma domestica) Terhadap Rendemen dan Skrining Fitokimia
}

\author{
Arista Wahyu Ningsih ${ }^{1}$, Iif Hanifa ${ }^{1}, A^{\prime}$ yunil Hisbiyah $^{1}$ \\ Program Studi S1 Farmasi STIKES RS ANWAR MEDIKA, Sidoarjo, Indonesia \\ Email:ariessmkkes@gmail.com/081334006809
}

\begin{abstract}
ABSTRAK : Kunyit (Curcuma domestica) adalah tanaman yang berada di daerah Asia Tenggara yang digunakan sebagai tanaman rempah dan obat. Tanaman ini kemudian mengalami perseberan ke Indonesia. Kunyit adalah tanaman obat yang memiliki peluang untuk dieksplorasi dalam pemanfaatannya. Tujuan dari penelitian ini yaitu untuk mengetahui perbedaan $\%$ rendemen dan skrining fitokimia dengan membandingkan metode ekstraksi maserasi dan remaserasi menggunakan pelarut etanol 96\%. Hasil rendemen paling tinggi adalah rendemen dengan menggunakan metode ekstraksi remaserasi sebesar $23.3 \%$ sedangkan ekstraksi menggunakan maserasi menghasilkan rendemen ekstrak sebesar $22 \%$. Hasil uji penapisan fitokimia terhadap ekstrak rimpang kunyit dengan teknik remaserasi dan maserasi keduanya sama-sama mengandung golongan senyawa alkaloid, flavonoid, tannin, polifenol, antrakuinon, triterpenoid dan steroid. Hasil dari analisis kualitatif dengan metode penapisan fitokimia menunjukkan bahwa metode ekstaraksi maserasi dan remaserasi tidak mempengaruhi kandungan senyawa kimia dalam tumbuhan tetapi mempengaruhi $\%$ rendemen ekstrak yang dihasilkan.
\end{abstract}

Kata kunci : Rendemen, maserasi, remaserasi

ABSTRACT : Kunyit, (Curcuma domestica) is a plant in south Asian region that used as herbs and medical plants. This plant spread out crossing to Indonesia. Kunyit is the one of the medicinal plants that has the potential to be explored in its use. The purpose of this study is to determine the difference in\% yield and phytochemical screening by comparing maceration extraction and remaseration methods using $96 \%$ ethanol solvent. The highest yield is the yield using the remaseration extraction method of $23.3 \%$ while extraction using maceration produces an extract yield of $22 \%$. The results of phytochemical screening tests on kunyit extract with remaseration and maceration techniques both contain classes of alkaloid compounds, flavonoids, tannins, polyphenols, anthraquinones, triterpenoids and steroids. The results of the qualitative analysis using the phytochemical screening method showed that the maceration and remaceration extinction method did not affect the content of chemical compounds in plants but influenced the\% of extract yield produced.

Keywords: Rendemen, maceration, remaseration

\section{PENDAHULUAN}

Kunyit, kunir (Curcuma domestica) adalah tanaman obat dan rempah di Indonesia yang banyak digunakan dalam terapi melancarkan proses peredaran darah di dalam tubuh, antiradang atau antiinflamasi pada proses menstruasi, memiliki sifat antibakteri dan bersifat sebagai adstringen yaitu memperkecil pori-pori wajah. Kunyit 


\section{Artikel Penelitian}

digunakan dalam terapi pencegahan dan pengobatan dalam berbagai penyakit. Penggunaan kunyit sebagai jamu secara turun temurun di masyarakat karena kunyit memiliki banyak senyawa metabolit sekunder yang memiliki efek farmakologis(Rahardjo et al., 2005).

Kunyit mengandung senyawa metabolit sekunder antara lain saponin, alkaloid, triterpenoid, flavonoid, tannin dan polifenol. Senyawa metabolit sekunder di dalam rimpang kunyit terdiri dari oleoresin, kurkumin, resin, minyak atsiri, desmetoksikurkumin dan bidesmetoksi kurkumin. Pewarna untuk makanan manusia memanfaatkan kurkumin sebagai zat warna kuning. Berbagai kandungan metabolit sekunder pada rimpang kunyit dapat dioptimalkan pemanfaatannya sehingga mendorong usaha dalam mengeksplorasinya (Winarto, 2004).

Dalam proses pengembangan obat tradisional, untuk isolasi metabolit sekunder aktif dari tanaman obat dapat menggunakan berbagai metode ekstraksi. Metode ekstraksi yang sering digunakan adalah maserasi, remaserasi, soxletasi, refluks dan perkolasi. Metode ekstraksi yang sering digunakan dalam penelitian adalah maserasi dan remaserasi. Alasan metode tersebut sering digunakan adalah perlakuan lebih sederhana karena tidak membutuhkan perlatan yang mahal, kandungan kimia dalam simplisia yang akan ditarik aman karena tidak menggunakan pemanasan. Kondisi percobaan seperti waktu ekstraksi, jenis pelarut dan sampel pelarut akan mempengaruhi efektivitas proses ekstraksi (Oktavia, 2011).

Kandungan metabolit sekunder utama didapatkan dengan cara melakukan optimasi dalam proses pembuatan ekstrak Metode ekstraksi adalah salah satu optimasi yang bisa dilakukan untuk menghasilkan kandungan metabolit sekunder utama. Banyaknya zat yang dapat tersari dapat dilihat dengan optimasi metode ekstraksi sehingga perlu dilakukan penelitian untuk membandingkan kandungan metabolit sekunder aktif pada ekstrak rimpang kunyit dengan metode maserasi dan remaserasi.

Salah satu metode yang digunakan untuk mengidentifikasi kandungan senyawa dari suatu tanaman adalah skrining fitokimia. Skrining fitokimia merupakan tahap pendahuluan yang dapat memberikan gambaran mengenai kandungan senyawa tertentu dalam bahan alam yang akan diteliti. Golongan senyawa yang terkandung dalam tanaman akan tergambar dari hasil skrining fitokimia dengan pengamatan perubahan warna secara visual (Roxb, 2012). 


\section{BAHAN DAN METODE}

\section{Alat Penelitian}

Alat yang digunakan dalam penelitian ini adalah maserator, neraca analitik, penangas air, seperangkat alat-alat gelas, cawan porselen, plat tetes, rotaryevaporator dan corong Buchner.

\section{Bahan Penelitian}

Bahan yang digunakan dalam penelitian ini adalah rimpang kunyit, etanol 96\%, ammonia, asam sulfat, asam asetat dan aquades.

\section{Tempat dan Waktu Penelitian}

Penelitian ini adalah penlitian eksperimental yang pelaksanaannya di Laboratorium Kimia Organik, STIKES RS Anwar Medika Sidoarjo pada bulan September-Februari 2019.

\section{PROSEDUR PENELITIAN}

\section{Pembuatan Serbuk Rimpang Kunyit}

Rimpang kunyit yang akan digunakan dicuci terlebih dahulu dengan meggunakan air mengalir kemudian di tiriskan. Rimpang kunyit yang sudah bersih dilakukan sortasi basah. Rimpang kunyit dirajang dan dilakukan pengeringan pada suhu $40^{\circ} \mathrm{C}$ di dalam oven.Simplisia rimpang kunyit dibuat serbuk jika sudah kering dengan cara diblender.

\section{Ekstraksi Metode Maserasi}

Pelarut etanol 96\% digunakan dalam proses ekstraksi dengan metode maserasi. 150 gram serbuk simplisia rimpang kunyit ditambahkan pelarut etanol 96\% sebanyak $1.125 \mathrm{~mL}$ dan dilakukan maserasi. Setelah seluruh serbuk direndam kemudian dilakukan pengadukan secara perlahan dan direndam selama 5 hari dengan dilakukan pengadukan. Maserat yang dihasilkan kemudian diuapkan dengan rotary evaporator pada suhu $50^{\circ} \mathrm{C}$ dan diuapkan sampai menjadi ekstrak kental.

\section{Ekstraksi Metode Remaserasi}

150 gram serbuk simplisia rimpang kunyit dimaserasi dengan pelarut etanol $96 \%$ sebanyak $450 \mathrm{~mL}$. Secara perlahan sambil diaduk hingga pelarut merendam seluruh serbuk kemudian direndam selama 24 jam dengan dilakukan pengadukan. Remaserasi dilakukan sebanyak 2 kali. Rotaryevaporator digunakan untuk menguapkan maserat yang telah disaring pada suhu $50^{\circ} \mathrm{C}$ dan diuapkan sampai menjdi eksrak kental. 


\section{Artikel Penelitian}

\section{Uji Flavonoid}

Ekstrak rimpang kunyit sebanyak 0.1 gram ditambah $0.1 \mathrm{mg}$ serbuk $\mathrm{Mg}, 0.4 \mathrm{ml}$ amil alcohol, dan $4 \mathrm{ml}$ etanol teknis 96\% kemudian campuran dikocok. Warna merah, kuning atau jingga yang terbentuk pada lapisan amil alcohol menunjukkan positif flavonoid.

\section{Uji Saponin}

Pengocokan selama 30 detik pada Ekstrak rimpang kunyit setelah ditambahkan 0.1 gram ditambah $10 \mathrm{ml}$ aqudest. Terbentuknya busa kurang lebih $1 \mathrm{~cm}$ menunjukkan positif adanya saponin.

\section{Uji Tanin}

$10 \mathrm{ml}$ aquadest ditambahkan pada ekstrak rimpang kunyit sebanyak 0.1 gram kemudian dilakukan penyaringan setelah didiamkan 5 menit. 5 tetes $\mathrm{FeCl} 31 \%$ diteteskan pada filtrate. Perubahan warna menjadi hitam atau biru menunjukkan hasil positif tannin.

\section{Uji Triterpenoid atau Steroid}

0.1 gram ekstrak rimpang kunyit ditimbang dan ditambahkan 3 tetes asetat anhidrat kemudian 1 tetes $\mathrm{H}_{2} \mathrm{SO}_{4}$ pekat. Steroid ditunjukkan dengan adanya prubahan warna hijau dan Triterpenoid ditunjukkan dengan adanya perubahan warna menjadi ungu atau merah.

\section{Uji Alkaloid}

5 gram ekstrak rimpang kunyit diekstrak dengan kloroform, disaring dan ditumbahkan asam sulfat dikocok dan dibagi menjadi 4 bagian. 1 bagian digunakan sebagai blanko dan 3 bagian masing-masing ditambahkan reagen mayer, dragendorf dan wagner. Positif mengandung alkaloid ditunjukkan dengan adanya endapan putih dan endapan coklat kemerahan.

\section{Uji Antrakuinon}

0.3 gram ekstrak rimpang kunyit diekstraksi dengan $10 \mathrm{ml}$ aquades, kemudian filtrate diekstraksi dengan $3 \mathrm{ml}$ toluene dan ditambah ammonia. Positif antrakuinon ditunjukkan dengan perubahan warna merah. 


\section{Artikel Penelitian}

\section{Uji Polifenol}

1 gram ekstrak rimpang kunyit diekstraksi dengan $15 \mathrm{~mL}$ aquades panas kemudian ditambah $\mathrm{NaCl}$ dan garam gelatin. Endapan yang timbul menunjukkan hasil positif polifenol.

\section{Analisis Data}

Penelitian ini menggunakan analisis data secara deskriptif. Data \% Rendemen di tampilkan dalam bentuk diagram dan tabel. Data kandungan senyawa kimia ditampilkan dalam bentuk tabel.

\section{HASIL DAN PEMBAHASAN}

1. Analisa Rendemen Ekstrak Rimpang Kunyit (Curcuma domestica)

Hasil ekstraksi diuapkan dengan alat rotary evaporator untuk menghlangkan pelarut alcohol 96\% yang digunakan. Proses penguapan pelarut dilakukan sampai ekstrak kental kemudian dilakukan perhitungan rendemen dari ekstrak yang didapatkan. Hasil rendemen ekstrak rimpang kunyit dari tiap pelarut, baik memakai metode ekstraksi maserasi maupun remaserasi dapat dilihat pada Tabel 1.

Tabel 1. Rendemen Hasil Ekstraksi

\begin{tabular}{|l|c|c|c|}
\hline $\begin{array}{l}\text { Metode } \\
\text { Ekstraksi }\end{array}$ & $\begin{array}{c}\text { B. Simplisia } \\
\text { (gram) }\end{array}$ & $\begin{array}{c}\text { B. } \\
\text { Ekstrak(gram) }\end{array}$ & $\begin{array}{c}\text { \% } \\
\text { Rendemen }\end{array}$ \\
\hline Remaserasi & 150 & 35 & 23.33 \\
\hline Maserasi & 150 & 33 & 22 \\
\hline
\end{tabular}

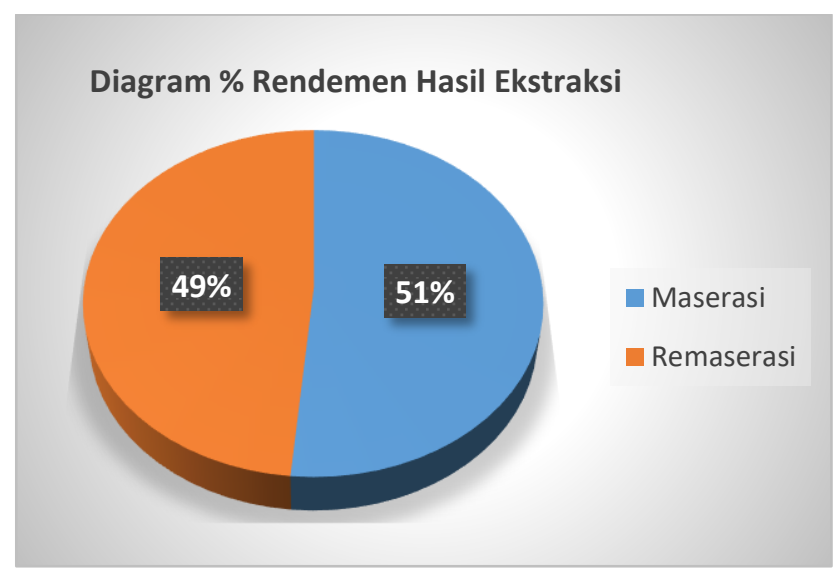

Gambar 1. Diagram \% Rendemen Hasil Ekstraksi 
2. Hasil Pengujian Skrining Fitokimia

Ekstrak yang dihasilkan dilakukan pengujian skrining fitokimia untuk mengidentifikasi golongan senyawa dalam ekstrak tersebut. Dari serangkaian pengujian skrining fitokimia ekstrak pada metode maserasi dan remaserasi tidak memiliki golongan senyawa saponin. Hasil pengujian skrining fitokimia ekstrak rimpang kunyit dari tiap pelarut, baik menggunakan metode ekstraksi maserasi maupun remaserasi dapat dilihat pada Tabel 2.

Tabel 2. Hasil Uji Penapisan Fitokimia

\begin{tabular}{|c|c|c|}
\hline Golongan Senyawa & Maserasi & Remaserasi \\
\hline Alkaloid & + & + \\
\hline Flavonoid & + & + \\
\hline Tanin & + & + \\
\hline Polifenol & + & + \\
\hline Antrakuinon & + & + \\
\hline Saponin & - & - \\
\hline Triterpenoid & + & + \\
\hline Steroid & + & + \\
\hline
\end{tabular}

Tabel 3. Gambar Uji Penapisan Fitokimia

\begin{tabular}{|c|c|c|c|c|}
\hline No. & $\begin{array}{c}\text { Senyawa } \\
\text { Metabolit }\end{array}$ & Hasil & Keterangan & Gambar \\
\hline 1. & Flavonoid & + & Terbentuk warna merah & \\
\hline 2. & Alkaloid & + & Terbentuk endapan & \\
\hline 3. & Saponin & - & Tidak terbentuk busa \\
stabil & & \\
\hline 4. & Triterpenoid & + & $\begin{array}{c}\text { Terbentuk warna merah } \\
\text { ungu }\end{array}$ & \\
\hline
\end{tabular}




\begin{tabular}{|c|c|c|c|c|}
\hline No. & $\begin{array}{c}\text { Senyawa } \\
\text { Metabolit }\end{array}$ & Hasil & Keterangan & Gambar \\
\hline 5. & Antrakunon & + & $\begin{array}{c}\text { Perubahan warna menjadi } \\
\text { semakin pekat }\end{array}$ & \\
\hline 6. & Tanin & + & Kuning kehitaman & \\
\hline 7. & Polifenol & + & Kuning kecoklatan & \\
\hline 8. & Steroid & & $\begin{array}{c}\text { Terbentuk warna merah } \\
\text { pekat }\end{array}$ & \\
\hline
\end{tabular}

Pada Penelitian ini data rendemen hasil ekstraksi menunjukkan perbedaan hasil rendemen baik metode ekstraksi atau metode remaserasi. Banyaknya rendemen bergantung kepada sifat kelarutan komponen bioaktifnya. Pada Tabel 1 menunjukkan bahwa metode estraksi secara remaserasi menghasilkan rendemen yang paling tinggi, metode ekstraksi remaserasi dapat menarik lebih maksimal senyawa biokatif pada rimpang kunyit. Rendemen dengan menggunakan metode ekstraksi remaserasi sebesar $23.33 \%$ sedangkan rendemen dengan menggunakan metode ekstraksi maserasi sebesar 22\%. Menurut (Sayuti, Barat and Pendahuluan, 2017) Waktu ekstraksi yang berbeda diduga menjadi penyebab perbedaan hasil rendemen tersebut. Kesetimbangan pada proses ekstraksi akan menyebabkan terjadinya kontak antara simplisia dengan air sehingga akan menarik senyawa metabolit sekundr utama akan lebih banyak karenasemakin lama waktu penyarian maka semaki banyak senyawa yang tertarik keluar. Selain factor waktu,volume pelarut juga mempengaruhi hasil rendemen karena semakin banyak volume yang digunakan maka semakin banyak tersebut menarik golongan senyawa pada tumbuhan tersebut.

Penelitian tentang parameter perbandingan metode ekstraksi antara maserasi dan remaserasi bertujuan untuk membuktikan bahwa metode ekstraksi yang digunakan 


\section{Artikel Penelitian}

dalam percobaan atau penelitian memberikan pengaruh perbedaan rendemen baik jumlah rendemen ekstrak ataupun golongan metabolit sekunder sehingga penelitian ini bisa memberikan gambaran penggunaan metode ekstraksi dalam memberikan hasil optimal dalam penarikan senyawa metabolit sekunder dalam tanaman. Metode ekstraksi yang digunakan adalah metode maserasi dan remaserasi. Pelarut yang digunakan adalah etanol 96\% karena pelarut ini memiliki tingkat keamanan dan kemudah dalam proses penguapan atau pemisahan pelarutnya, serta senyawa yang bersifat nonpolar, polar dan semipolar dapat dilarutkan (Pharmascience et al., 2015).

Hasil penelitian menunjukkan bahwa perbedaan metode ekstraksi maserasi dan remaserasi akan menghasilkan perbedaan rendemen, dimana metode remaserasi akan membuat rendemen yang lebih tinggi dibandingkan dengan maserasi. Peningkatan kemampuan untuk menarik senyawa metabolit sekunder pada rimpang kunyit lebih maksilam pada metode remaserasi karena adanya siklus pergantian pelarut dalam proses ekstraksi, sedangkan pada metode maserasi semua metabolit sekunder dalam tanaman tidak tertarik secara optimal oleh pelarut yang digunakan karena dalam siklus ekstraksi tidak terjadi pergantian pelarut. (Nurhasnawati et al., 2017).

Prinsip kerja remaserasi adalah pelarutan senyawa metabolit sekunder pada sampel berdasarkan sifat kelarutannya dalam suatu pelarut. Pada temperature kamar dan terlindung dari cahaya dilakukan proses penarikan senyawa metabolit sekunder selama tiga hari dengan cara merendam serbuk simplisia dengan pelarut yang sesuai selama tiga hari dan dilakukan pergantian pelarut tiap hari. Ketika sudah mencapai fase setimbang sel tanaman tersebut akan dimasuki oleh pelarut dengan cara melewati dinding sel. Proses setimbang tersebut terjadi dengan cara keluarnya senyawa metabolit sekunder di dalam sel karena konsentrasi di dalam sel berbeda dengan konsentrasi d luar sel. Proses setimbang tersebut terjadi karena ada proses difusi yang disebabkan karena adanya perbedaan konsentrasi dimana konsentrasi di dalam sel yang lebih tinggi akan menyebabkan senyawa metabolit sekunder keluar dan digantikan oleh cairan pelarut di luar sel yang konsentrasinya lebih rendah. Peristiwa tersebut terjadi berulang sampai terjadi keseimbangan konsentrasi di luar dan di dalam sel. Selama proses remaserasi dilakukan penggantian cairan penyari setiap hari selama 3 hari sehingga efektivitas penarikan akan lebih maksimal (Info et al., 2013). 
Hasil uji penapisan fitokimia menunjukkan bahwa ekstrak etanol rimpang kunyit mengandung golongan senyawa alkaloid, flavonoid, tannin, polifenol, antrakuinon, triterpenoid dan steroid. Berbagai macam kandungan metabolit sekunder pada rimpang kunyit ini dilakukan dengan pengujian skrining fitokimia. Hasil yang sama juga didapatkan pada penelitian Sri Agustina dkk (2016) pada jurnal Cakra Kimia.

\section{KESIMPULAN}

Berdasarkan hasil dan analisa data dapat disimpulkan bahwa perbedaan metode ekstraksi, memberikan pengaruh terhadap rendemen hasil ekstraksi rimpang kunyit. Metode ekstraksi remaserasi memberikan hasil \% rendemen yang lebih besar yaitu $23,33 \%$ dibandingkan dengan metode ekstraksi maserasi yaitu 22\%. Namun, perbedaan metode ekstraksi tidak mempengaruhi dalam penarikan senyawa bioaktif pada tanaman.

\section{DAFTAR PUSTAKA}

1. Info, C. et al. (2013) 'Pengaruh Jenis Pelarut Pada Ekstraksi Kurkuminoid Dari Rimpang Temulawak ( Curcuma xanthorrhiza Roxb )', 1(1), pp. 101-107.

2. Nurhasnawati, H. et al. (2017) 'Kadar Flavonoid Ekstrak Etanol Umbi Bawang Dayak (Eleutherine Palmifolia ( L .) Merr ) Dengan Metode Spektrofotometri Effect Of The Extraction Method On The Concentrationof Flavonoids Ethanol Extract Of Onion Dayak Bulbs ( Eleutherine palmifolia ( L .) Merr ) USING SPECTROPHOTOMETRY', 01(01), pp. 1-9.

3. Pharmascience, J. et al. (2015) 'Formulasi Mikroemulsi Ekstrak Bawang Hutan dan Uji Aktivitas Antioksidan', 2(2), pp. 1-14.

4. Rahardjo, M. et al. (2005) 'Budidaya tanaman kunyit', (11).

5. Roxb, Z. (2012) 'Skrining Fitokimia Ekstrak Metanol Rimpang Bangle (', (2009).

6. Sayuti, M., Barat, P. and Pendahuluan, A. (2017) 'Pengaruh Perbedaan Metode Ekstraksi , Bagian Dan Jenis Pelarut Terhadap Rendemen Dan Aktifitas Antioksidan Bambu Laut ( Isis', 1(3), pp. 166-174. 